\title{
KNOWLEDGE AND PRACTICE MODIFICATIONS REGARDING COVID-19 AMONG DENTAL PRACTITIONERS OF NEPAL
}

\author{
Rebicca Ranjit ${ }^{1^{*}}$, Pratik Manandhar ${ }^{2}$, Soni Bista ${ }^{1}$, Elijma Ranjit ${ }^{3}$
}

\begin{abstract}
Affiliation
1. Lecturer, Department of Periodontology \& Oral Implantology, Gandaki Medical College Teaching Hospital \& Research Centre, Pokhara, Nepal

2. Lecturer, Department of Prosthodontics \& Maxillofacial Prosthetics, Gandaki Medical College Teaching Hospital \& Research Centre, Pokhara, Nepal

3. Dental Surgeon, People's Dental College \& Hospital Pvt. Ltd. Kathmandu, Nepal
\end{abstract}

\section{ARTICLE INFO}
Received : 14 January, 2021
Accepted : 09 July, 2021
Published : 04 November, 2021

(C) Authors retain copyright and grant the journal right of first publication with the work simultaneously licensed under Creative Commons Attribution License CC - BY 4.0 that allows others to share the work with an acknowledgment of the work's authorship and initial publication in this journal.

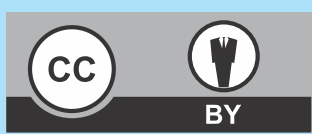

\section{ORA 250}

DOI: https://doi.org/10.3126/bjhs.v6i2.40318

* Corresponding Author

Dr. Rebicca Ranjit

Lecturer

Department of Periodontology \& Oral Implantology Gandaki Medical College Teaching Hospital \& Research Centre, Pokhara, Nepal

Email: rebiranjit@gmail.com

ORCID: https://orcid.org/0000-0003-0619-7257

\section{Citation}

Rebicca Ranjit, Pratik Manandhar, Soni Bista, Elijma Ranjit. Knowledge and Practice Modifications regarding COVID-19 among dental practitioners of Nepal. BJHS 2021;6(2)15. 1454-1459.

\section{ABSTRACT}

\section{Introduction}

COVID-19 has adversely gridlocked many sectors including dentistry. A good knowledge regarding the disease eventually determines the preparedness of dentists to provide relatively safe dental services.

\section{Objectives}

This research was conducted to evaluate knowledge and relevant practice modifications among dental practitioners of Nepal during COVID-19 pandemic.

\section{Methodology}

A cross-sectional online questionnaire survey was conducted among dental practitioners of all the provinces of Nepal. They were enquired for sociodemographic details and their knowledge, and the modifications they adopted while practising dentistry during this pandemic. The scores were summed up, and mean scores for knowledge and practice were calculated respectively which were further expressed as a percentage. Inferential statistics (Independent t-test and ANOVA, $p<0.05)$ were used to examine differences between study variables.

\section{Result}

Out of 422 participants, most of them belonged to $f 30$ years age group (226, 53.6\%) and majority were females (246, $58.3 \%)$. Mean knowledge scores were significantly higher among practitioners of age $\geq 51$ years, males, specialists, those working in both clinic and hospital, and those who have been practising dentistry for $\geq 10$ years. Mean practice scores were significantly better among specialists.

\section{Conclusion}

The overall mean scores for knowledge was good (81.3\%) while for practice, overall mean score was poor (44.6\%). The main reason behind the poor practice modifications despite good knowledge score could be the lack of minimum requirements for infection control in developing countries like Nepal.

\section{KEYWORDS}

COVID-19; dental practitioners; dentistry; infection control; pandemic. 


\section{INTRODUCTION}

The outbreak of COVID-19 has spread exponentially worldwide within short timespan and Nepal is not an exception. ${ }^{1}$ Despite adopting tremendous measures, innumerable cases prevail nationwide, leaving every sectors standstill, including dentistry. The increased threat of crossinfection and rising financial burden have caused psychological distress to dentists.

Most routine dental procedures generate aerosols. ${ }^{2}$ Moreover, dentists work in close proximity to patients, thereby increasing risk of cross-contamination and infection spread. Thus, to provide relatively safe dental care to patients and to ensure safety of entire dental team, dentists should upgrade their insight regarding the disease, follow recommended guidelines on infection control, and consider relevant practice modifications. Researches across globe have shown that dentists have good knowledge, and practice regarding COVID-19, which eventually determines their preparedness to provide services during pandemic. ${ }^{3.5}$

To the authors' best understanding, this study is one of the first few attempts undertaken to evaluate knowledge and practice modifications regarding COVID-19 among dental practitioners from all provinces of Nepal.

\section{METHODOLOGY}

A cross-sectional study was conducted from $10^{\text {th }}$ August to $10^{\text {th }}$ October 2020 among the dental practitioners of Nepal using an online questionnaire prepared through Google Forms. The online survey was preferred due to the pandemic situation, increased risk of conducting a paper-form survey and the urgency of data collection considering the situation. Ethical approval was obtained from the National Health Research Council (Regd. No. 551/2020P). Electronic informed consent was provided on the first page of the survey and the positive response was considered as implied consent. Consecutive sampling method was used and sample size of 384 was calculated taking prevalence as $50 \%$. The total sample size of 422 was calculated after adding $10 \%$ non-response rate. The questions were developed after reviewing relevant literatures and various proposed guidelines by $\mathrm{CDC}$ and $\mathrm{WHO}^{2,6-10}$ Before conducting the final study, the questionnaires were validated by sending it to the experts. It was then pretested amongst $10 \%$ of total sample size and the relevant modifications were made based on the responses of the participants. The subjects of pretesting were not included in the main sample. All the dental practitioners with Nepal Medical Council (NMC) registration were included in the study while the respondents from pretesting, the unwilling/non-respondents, and those who were not currently practising dentistry were excluded. The dental professionals were accessed through various social media (email, messenger, viber, etc.). The first set of questionnaires were mailed from $10^{\text {th }}$ to $20^{\text {th }}$ August, 2020. The three reminders were then sent at one week's interval each on $27^{\text {th }}$ August, $3^{\text {rd }}$ September, and $9^{\text {th }}$ September, 2020 respectively. The data collection was then closed on $10^{\text {th }}$ October 2020.

The participants were enquired for demographic details like gender, age, designation, provinces they are currently working in, workplace, work setting and their years of dental practice. The questionnaire consisted of 20 close-ended questions (knowledge-11, and practice-9). The knowledge was assessed using dichotomous response ( $\mathrm{Yes} / \mathrm{No}$ ) and each negative response was scored as 0 while the positive response was given a score of 1 . The practice responses were evaluated using a 5-point Likert scale (always-5, often4 , sometimes-3, rarely-2, never-1). At the end of survey, the participants were provided with the relevant facts, proposed guidelines and recommendations in a concise form with the aim of broadening their knowledge regarding the measures that should be adopted while practising dentistry during this pandemic.

The maximum possible scores for knowledge and practice questions were 11 , and 45 respectively. The scores for all the questions were summed up and the mean scores for knowledge and practice were calculated respectively. The scores were expressed as percentage which were further interpreted as good ( $\geq 80 \%)$, fair (60-79\%) and poor $(<60 \%){ }^{8}$ The obtained data were entered into the excel sheet and data analysis was done using statistical package for social sciences version 16.0. Univariate analysis such as frequencies, percentage, mean and standard deviation of demographic variables, knowledge and practice were calculated. Furthermore, independent $t$-test and ANOVA were used to assess the difference between mean knowledge and practice scores in accordance with the various socio-demographic variables.

\section{RESULTS}

\section{Socio-demographic Characteristics:}

A total of 422 dental practitioners completed the web-based survey with the response rate of $54.38 \%$. The background characteristics of the respondents are displayed in Table 1. Of the total sample, 226(53.6\%) were from $£ 30$ years age group. $246(58.3 \%)$ were females, and most of them belonged to Bagmati province $(158,37.4 \%)$ while only 8 (1.9\%) were from Sudurpaschim Province. In addition, most of them $(220,52.1 \%)$ were general dental practitioners, majority $(167,39.6 \%)$ were working in clinics, $322(76.3 \%)$ were doing private practice, and $221(52.4 \%)$ had been practising dentistry since $f 5$ years. 
Table 1: Sociodemographic characteristics of the participants ( $\mathrm{N}=422$ )

\begin{tabular}{|c|c|c|c|}
\hline \multicolumn{2}{|c|}{ Sociodemographic Variables } & \multirow{3}{*}{$\begin{array}{c}\begin{array}{c}\text { Frequency } \\
\text { (N = 422) }\end{array} \\
\begin{array}{c}176 \\
246\end{array}\end{array}$} & \multirow{3}{*}{\begin{tabular}{|c|} 
Percentage \\
41.7 \\
58.3
\end{tabular}} \\
\hline Sex & Male & & \\
\hline sex & Female & & \\
\hline \multirow{4}{*}{ Age-group } & $\leq 30$ years & 226 & 53.6 \\
\hline & $31-40$ years & 178 & 42.2 \\
\hline & $41-50$ years & 12 & 2.8 \\
\hline & $\geq 51$ years & 6 & 1.4 \\
\hline \multirow{7}{*}{$\begin{array}{l}\text { Currently } \\
\text { working } \\
\text { province }\end{array}$} & Province no 1 & 64 & 15.2 \\
\hline & Province no 2 & 25 & 5.9 \\
\hline & Bagmati Province & 158 & 37.4 \\
\hline & Gandaki Province & 72 & 17.1 \\
\hline & Lumbini Province & 78 & 18.5 \\
\hline & Karnali Province & 17 & 4 \\
\hline & Sudurpaschim Province & 8 & 1.9 \\
\hline \multirow{2}{*}{ Designation } & General dental & 220 & 52.1 \\
\hline & $\begin{array}{l}\text { practitioner } \\
\text { Specialist }\end{array}$ & 202 & 47.9 \\
\hline \multirow{3}{*}{ Work place } & Hospital & 162 & 38.4 \\
\hline & Clinic & 167 & 39.6 \\
\hline & Both & 93 & 22 \\
\hline \multirow{2}{*}{ Work setting } & Private & 322 & 76.3 \\
\hline & Government & 100 & 23.7 \\
\hline \multirow{3}{*}{$\begin{array}{l}\text { Years of } \\
\text { dental } \\
\text { practice }\end{array}$} & $<5$ years & 221 & 52.4 \\
\hline & $5-10$ years & 144 & 34.1 \\
\hline & $>10$ years & 57 & 13.5 \\
\hline
\end{tabular}

Knowledge regarding COVID-19 and its association with sociodemographic variables:

The obtained mean knowledge score was $9.70 \pm 1.41$ having an overall $88.2 \%$ of positive response rate. Of the total, 343 (81.3\%) had good, 66 (15.6\%) had fair and 13 (3.1\%) had poor knowledge of COVID-19. As depicted in Figure 1, almost all of the dental practitioners were aware of the symptoms of COVID-19 (418, 99.1\%), the incubation period $(408,96.7 \%)$, its modes of transmission (421, 99.8\%), and about the positive method of donning and doffing the personal protective equipment (PPE) $(338,80.1 \%)$.

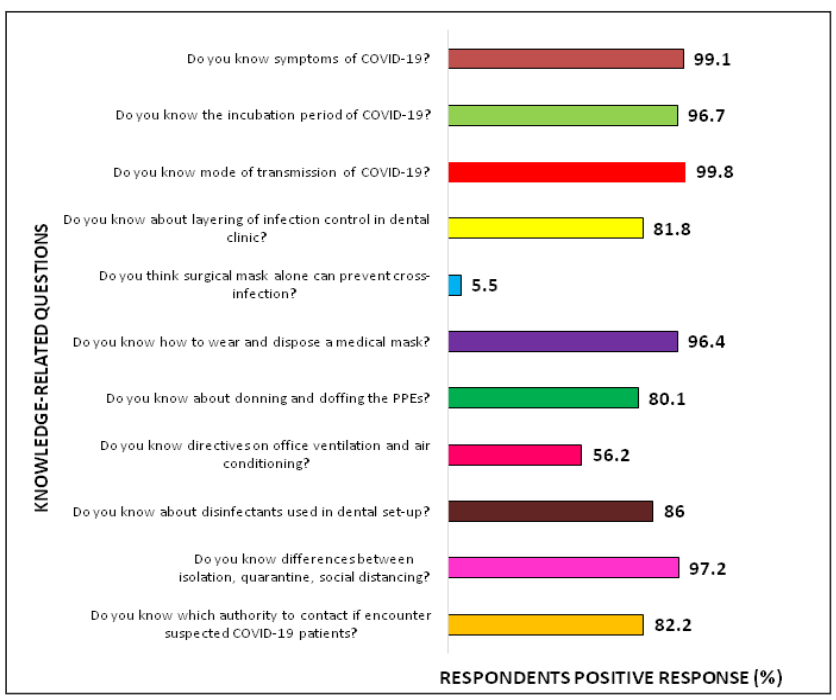

Figure 1: Knowledge about COVID-19 among dental practitioners of Nepal.

Table 2 outlines the difference in mean knowledge scores in accordance with sociodemographic variables. Males had greater mean knowledge score than females and specialists were found to have greater mean knowledge score in comparison to general dental practitioners which was statistically significant $(p$-value $=0.005, p$-value $<0.001$, respectively). A statistically significant difference in mean knowledge score was found between different age-groups, workplace and years of dental practice. Further analysis with post-hoc (Tukey test) for age-groups showed that there was a statistically significant difference in mean knowledge score between 30 years and 31-40 years (mean knowledge of 3140 years $>30$ years, $p$-value $<0.001$ ) and between 30 years and $41-50$ years (mean knowledge of $41-50$ years $>30$ years, p-value $=0.02$ ). Post-hoc (Tukey test) for workplace showed a statistically significant differences in mean knowledge scores between dental practitioners working in hospitals and clinics ( $p$-value $=0.03$ ) and between those working in both and clinics ( $p$-value $<0.001)$. Dental practitioners working in hospitals and working in both had greater mean knowledge scores than those working in clinics. Mean knowledge score of those who have worked for less than 5 years had lesser mean knowledge scores as compared to those who have worked for 5-10 years and more than 10 years. Further analysis with post-hoc (Tukey test) showed a statistically significant difference in mean knowledge scores between those who worked $<5$ years and $5-10$ years ( $p$ value $<0.001$ ) and between those who worked $<5$ years and $>10$ years ( $p$-value $<0.001)$. Dental practitioners working in Sudurpaschim province, and those practising in government set-up had greater mean knowledge score. However, it was not statistically significant.

\begin{tabular}{|c|c|c|c|c|c|c|c|}
\hline \multicolumn{2}{|c|}{ Sociodemographic variables } & \multirow{2}{*}{$\begin{array}{c}\begin{array}{c}\text { Mean } \\
\text { knowledge } \\
\text { score } \\
\text { ( } \pm \text { S.D.) }\end{array} \\
9.93 \pm 1.27 \\
9.54 \pm 1.49\end{array}$} & \multirow{2}{*}{$\begin{array}{r}t / F \\
2.818\end{array}$} & \multirow{2}{*}{$\begin{array}{l}\text { p-value } \\
0.005^{*}\end{array}$} & \multirow{2}{*}{$\begin{array}{c}\begin{array}{c}\text { Mean } \\
\text { practice } \\
\text { score } \\
( \pm \text { S.D. })\end{array} \\
5.82 \pm 1.64 \\
5.70 \pm 1.35\end{array}$} & \multirow{2}{*}{$\begin{array}{l}t / F \\
0.789\end{array}$} & \multirow{2}{*}{$\begin{array}{r}\begin{array}{c}\text { p- } \\
\text { value }\end{array} \\
0.43\end{array}$} \\
\hline $\mathrm{Sex}^{+}$ & $\begin{array}{l}\text { Male } \\
\text { Female }\end{array}$ & & & & & & \\
\hline Age-group ${ }^{\ddagger}$ & $\begin{array}{l}\leq 30 \text { years } \\
31-40 \text { years } \\
41-50 \text { years } \\
\geq 51 \text { years }\end{array}$ & $\begin{array}{l}9.39 \pm 1.55 \\
10 \pm 1.17 \\
10.58 \pm 0.52 \\
10.67 \pm 0.52\end{array}$ & 9.359 & $<0.001^{*}$ & $\begin{array}{l}5.64 \pm 1.52 \\
5.94 \pm 1.42 \\
5.42 \pm 1.51 \\
5.17 \pm 0.75\end{array}$ & 1.939 & 0.12 \\
\hline $\begin{array}{l}\text { Currently } \\
\text { working } \\
\text { province }^{\ddagger}\end{array}$ & $\begin{array}{l}\text { Province no } 1 \\
\text { Province no } 2 \\
\text { Bagmati Province } \\
\text { Gandaki Province } \\
\text { Lumbini Province } \\
\text { Karnali Province } \\
\text { Sudurpaschim } \\
\text { Province }\end{array}$ & $\begin{array}{l}9.58 \pm 1.39 \\
9.80 \pm 1.19 \\
9.84 \pm 1.48 \\
9.68 \pm 1.43 \\
9.53 \pm 1.37 \\
9.41 \pm 1.37 \\
10.13 \pm 1.13\end{array}$ & 0.780 & 0.59 & $\begin{array}{l}5.67 \pm 1.40 \\
5.96 \pm 1.69 \\
5.87 \pm 1.31 \\
5.57 \pm 1.62 \\
5.94 \pm 1.61 \\
5.00 \pm 1.37 \\
4.88 \pm 1.25\end{array}$ & 1.894 & 0.08 \\
\hline Designation $^{\dagger}$ & $\begin{array}{l}\text { General dental } \\
\text { practitioner } \\
\text { Specialist }\end{array}$ & $\begin{array}{l}9.36 \pm 1.52 \\
10.06 \pm 1.18\end{array}$ & -5.253 & $<0.001^{*}$ & $\begin{array}{l}5.61 \pm 1.54 \\
5.91 \pm 1.39\end{array}$ & 2.083 & $0.04 *$ \\
\hline Work place ${ }^{\ddagger}$ & $\begin{array}{l}\text { Hospital } \\
\text { Clinic } \\
\text { Both }\end{array}$ & $\begin{array}{l}9.78 \pm 1.27 \\
9.4 \pm 1.51 \\
10.09 \pm 1.36\end{array}$ & 7.747 & $<0.001^{*}$ & $\begin{array}{l}5.69 \pm 1.36 \\
5.72 \pm 1.54 \\
5.92 \pm 1.55\end{array}$ & 0.847 & 0.43 \\
\hline $\begin{array}{l}\text { Work } \\
\text { setting }\end{array}$ & $\begin{array}{l}\text { Private } \\
\text { Government }\end{array}$ & $\begin{array}{l}9.63 \pm 1.44 \\
9.92 \pm 1.32\end{array}$ & -1.797 & 0.07 & $\begin{array}{l}5.80 \pm 1.49 \\
5.58 \pm 1.43 \\
\end{array}$ & 1.358 & 0.18 \\
\hline $\begin{array}{l}\text { Years of } \\
\text { dental } \\
\text { practice }^{\ddagger}\end{array}$ & $\begin{array}{l}<5 \text { years } \\
5-10 \text { years } \\
>10 \text { years }\end{array}$ & $\begin{array}{l}9.36 \pm 1.54 \\
9.94 \pm 1.20 \\
10.40 \pm 0.92\end{array}$ & 16.6 & $<0.001^{*}$ & $\begin{array}{l}5.70 \pm 1.52 \\
5.79 \pm 1.47 \\
5.86 \pm 1.34\end{array}$ & 0.358 & 0.69 \\
\hline
\end{tabular}

${ }^{*} p$-value $<0.05$ statistically significant, ${ }^{\dagger}$ Independent t test, ${ }^{\ddagger}$ ANOVA

Practice modifications regarding COVID-19 and its association with sociodemographic variables:

The mean practice score was obtained as $5.75 \pm 1.47$. Of the total dental practitioners, 52 (12.3\%) had good, 182 (43.1\%) 
had fair and 188 (44.6\%) had poor practice during Covid-19 outbreak. Figure 2 illustrates that most of the dental practitioners adopted the basic practice modifications during COVID-19 outbreak such as hand hygiene (421, $99.8 \%)$, routine use of PPE $(412,97.6 \%)$, and performing pre-procedural mouth rinse $(406,96.2 \%)$. Out of all the sociodemographic variables, the statistically significant mean difference in practice score was found in designation only ( $p$-value=0.04), where specialists had more mean practice score (Table 2 ).

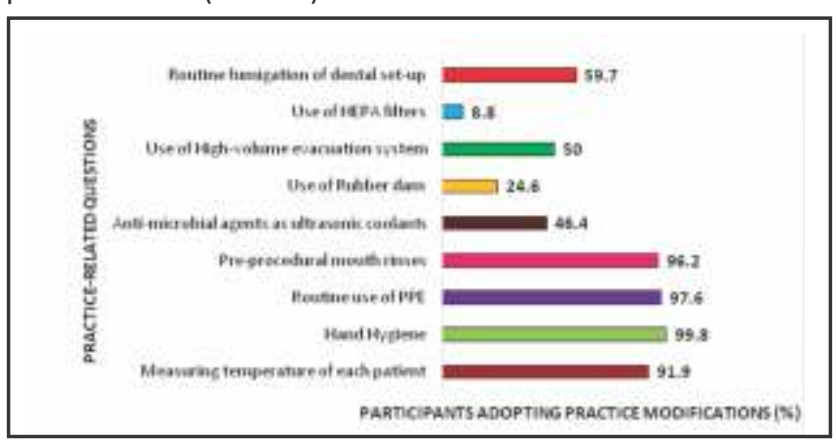

Figure 2: Practice modifications regarding COVID-19 among dental practitioners of Nepal.

\section{DISCUSSION}

Since the outbreak of COVID-19, the chaos created by it has been escalating worldwide leaving every sector gridlocked, including dentistry. With the intensifying repercussions of COVID-19 all over the world, various dentists either have tailored their practices to emergency treatment only or have stopped dental services for an indecisive time. It is an undeniable fact that dental practitioners should be aware of the risks and seriousness of this pandemic situation and should adopt a high level of awareness to deal with disease and be able to control and manage its spread. ${ }^{6,11}$ This survey on knowledge and practice regarding COVID-19 aids in collecting the information on what is known believed and done by dental practitioners of Nepal.

In the present study, majority of the dental practitioners in Nepal $(343,81.3 \%$ ) have a good knowledge regarding COVID-19, which is similar to the findings among the dentists of several countries. ${ }^{3,6,12,13}$ Better knowledge score was found in males than female counterparts, which is consistent with the findings by Althomairy et al. ${ }^{14}$ On the contrary, no significant relationship between sex and knowledge scores was found in studies by Gambhir et al, and Singh et al. ${ }^{4,8}$ Furthermore, the participants with $\geq 51$ years of age-group and those who have been practising dentistry for $>10$ years had better knowledge score which could be due to the increasing knowledge and learning experience with the growing age. Good knowledge scores were significantly associated with the years of practice in a study conducted among the dentists of various countries while some studies have shown no significant relationship between knowledge scores and work experience of subjects. ${ }^{3,4}$ Moreover, knowledge scores of dentists practising in both hospital and clinics were more and this finding is in congruence with the study done by Gambhir et al. ${ }^{4}$
Overall practice score among the dental practitioners of Nepal was found to be poor (44.6\%). In contrast to the finding of our study, good practice scores were observed in the dentists of other countries. ${ }^{3,15}$ The main reason behind the poor practice modifications despite good knowledge scores could be the lack of minimum requirements for infection control in the developing countries like Nepal. More than $90 \%$ of dental practitioners adopted basic practice modifications like measuring the temperature of each patient, pre-procedural mouth rinses, use of PPE while performing dental procedures. In a study conducted among the dentists of 30 different countries, $74 \%$ did not ask their patients to perform pre-procedural mouth rinses although it is believed to reduce salivary oral microbes. ${ }^{7}$ Similarly, hand hygiene has been considered the most vital measure for minimizing the risk of transmitting microorganisms to patients. In our study, $99.8 \%$ of subjects used alcohol-based hand rub or soap and water to clean their hands after treating patients, which is consistent with the study done by Alzoubi et al (99.7\%). ${ }^{16}$ Although majority of dentists agreed that the recommended precautions should be practised for every patient, unfortunately, only handful number of respondents have been using effective cross-infection control measures such as rubber dam, high-volume evacuation (HVE) system, and high-efficiency particulate air (HEPA) filters. ${ }^{7}$ In addition to these, fumigation of the dental operatory with drawers open should be done at least once a week to make the operating area completely sterile. However, only $59.7 \%$ of subjects routinely fumigated their dental set-ups in our study. Among the sociodemographic parameters considered in this study, good knowledge and practice scores were observed among the specialists. This finding is consistent with the studies amongst the dentists of other countries. ${ }^{4,8,12}$ stressing on the positive impact of education and learning experience on knowledge scores and their implementation in practice. On the contrary, age, sex, province, work setting, and years of dental practice did not show any significant differences in practice scores.

Currently, recommendations are based on experiences and pertinent guidelines in addition to the universal crossinfection control precautions. ${ }^{17,18}$ Some of the practice modifications that should be adopted during this pandemic include thermal monitoring of patients, taking medical and travel history, pre-procedural mouth rinses, hand hygiene, proper donning and doffing of PPE (gown, eyewear, face shields, boots with or without covers, cap, double gloving), use of filtering face piece respirators (FFP) available at different performance levels such as FFP2/N95, FFP3/N99, proper ventilation, disinfection, andr outine fumigation of set-up ${ }^{2,18-22}$ Additionally, replacing intra-oral radiographs by extra-oral radiographs such as orthopantomogram, and cone-beam computed tomography wherever possible, substituting periodontal procedures utilizing ultrasonic scalers with hand scalers can reduce the production and spread of aerosols, and splatter. ${ }^{2}$ Similarly, the use of rubber dam, high-volume suction helps to reduce aerosols and prevent droplets originating in the patient's oral cavity and 
respiratory tract from spreading and potentially transmitting infection. ${ }^{7}$ Currently, dental regulatory authorities in the world are urging dentists to conduct only emergency dental treatments and defer all the elective or non-essential procedures until the situation is under control. ${ }^{2,7}$ However, the public need for emergency dental care even during this pandemic will always be inevitable. Therefore, the dentists must be fully prepared for providing relatively safe dental services and must attain proper awareness to limit the disease spread. ${ }^{8}$ Until then, incorporating teledentistry into routine dental practice can offer a novel solution to resume dental practice that can, at least, complement the existing compromised dental system during the current pandemic. ${ }^{23}$

\section{CONCLUSION}

This study provides an insight into the level of knowledge and practice about COVID-19 among dental practitioners of Nepal and shows that they have poor practice modifications despite having a good knowledge regarding the disease. Practising dentistry amidst the upsurge of COVID-19 should be a learning experience for Nepal not only on emergency management but also towards developing a strong surveillance system and taking preventive actions for similar events in future. This study brings into notice about the existing flaws, which in turn, may help in shaping future guidelines, strategies and implementing effective infection control policies in dental settings.

\section{REFERENCES}

1. Shrestha R, Shrestha S, Khanal P, Bhuvan KC. Nepal's First Case of COVID-19 and public health response. J Travel Med. 2020;27 (3):1-6. DOI: 10.1093/jtm/taaa024

2. Meng L, Hua F, Bian Z. Coronavirus Disease 2019 (COVID-19): Emerging and future challenges for dental and oral medicine. J Dent Res. 2020;99(5):481-7. DOI: 10.1177/0022034520914246

3. Kamate SK, Sharma S, Thakar S, Srivastava D, Sengupta K, Hadi AJ, et al. Assessing Knowledge, Attitudes and Practices of dental practitioners regarding the COVID-19 pandemic: A multinational study. Dent Med Probl. 2020;57(1):11-7. DOI: 10.17219/ dmp/ 119743

4. Singh Gambhir R, Singh Dhaliwal J, Aggarwal A, Anand S, Anand V, KaurBhangu A. Covid-19: a survey on knowledge, awareness and hygiene practices among dental health professionals in an Indian scenario. RoczPanstwZaklHig. 2020;71(2):223-9. DOI: 10.32394/ rpzh.2020.0115

5. Gaffar BO, El Tantawi M, Al-Ansari AA, AlAgI AS, Farooqi FA, Almas KM. Knowledge and practices of dentists regarding MERS-CoV. A cross-sectional survey in Saudi Arabia. Saudi Med J. 2019;40(7): 714-20. DOI: 10.15537/smj.2019.7.24304

6. Khader Y, Al Nsour M, Al-Batayneh OB, Saadeh R, Bashier H, Alfaqih $M$, et al. Dentists' awareness, perception, and attitude regarding COVID-19 and infection control: cross-sectional study among Jordanian dentists. JMIR Public Health Surveill. 2020;6(2):e18798. DOI: $10.2196 / 18798$

7. Ahmed MA, Jouhar R, Ahmed N, Adnan S, Aftab M, Zafar MS, et al. Fear and Practice Modifications among Dentists to Combat Novel Coronavirus Disease (COVID-19) Outbreak. Int J Environ Res Public Health. 2020;17(8):2821. DOI: 10.3390/ijerph17082821

\section{LIMITATIONS OF STUDY}

This study still bear some limitations. The responses were based on practitioners' self-assessment rather than being provided under the supervision of the investigators. Additionally, it is an undeniable fact that the knowledge of dentists may alter with the emerging research and possible treatment strategies.

\section{ACKNOWLEDGEMENT}

We would like to acknowledge all the participants who spared their time to fill the questionnaires. We would also like to express our special thanks to Dr. Nuwadutta Subedi, Associate Professor, Department of Forensic Medicine, Gandaki Medical College, Pokhara for helping us throughout the manuscript, Dr. Anju Khapung, Lecturer, Department of community Dentistry, Nepal Medical College, Kathmandu and Dr. Nisha Gurung, Lecturer, Department of community Medicine, Gandaki Medical College, Pokhara for their significant help with statistics, and valuable suggestions for preparing the manuscript.

\section{CONFLICT OF INTEREST}

None

\section{FINANCIAL DISCLOSURE}

We did not receive any financial support for the conduction of this research as well as to prepare this article.

8. Singh KT, Mishra G, Shukla AK, Behera S, Tiwari AK, Panigrahi S, et al. Preparedness among dental professionals towards COVID-19 in India. Pan Afr Med J. 2020;36(108). DOI: 10.11604/pamj. 2020.36. 108.23694

9. Interim infection prevention and control guidance for dental settings during the coronavirus disease 2019 (COVID-19) pandemic [Internet]. Atlanta: Centers for Disease Control and Prevention; [cited 2020 Aug 28]. Available from: https://www.cdc.gov/ coronavirus /2019-ncov/hcp/dental-settings.html

10. Q\&A on coronaviruses (COVID-19) [Internet]. Geneva: World Health Organization; [cited 2020 Apr 15]. Available from: https:// www.who.int/news-room/q-a-detail/q-a-coronaviruses

11. Halboub ES, Al-Maweri SA, Al-Jamaei AA, Tarakji B, AI-Soneidar WA. Knowledge, Attitudes, and Practice of Infection Control among Dental Students at Sana'a University, Yemen.JInt Oral Health. 2015;7(5):15-9. DOI: 10.4103/0976-237X.128673

12. Quadri MFA, Jafer MA, Alqahtani AS, Almutahar SAB, Odabi NI, Daghriri AA, et al. Novel corona virus disease (COVID-19) awareness among the dental interns, dental auxiliaries and dental specialists in Saudi Arabia: A nationwide study. J Infect Public Health. 2020;13(6):856-64. DOI: 10.1016/j.jiph.2020.05.010

13. Modi PD, Nair G, Uppe A, Modi J, Tuppekar B, Gharpure AS, et al. COVID-19 Awareness Among Healthcare Students and Professionals in Mumbai Metropolitan Region: A Questionnaire-Based Survey. Cureus. 2020;12(4):e7514. DOI: 10.7759/cureus.7514

14. Althomairy SA, Baseer MA, Assery M, Alsaffan AD. Knowledge and attitude of dental health professionals about middle east respiratory syndrome in Saudi Arabia. J IntSocPrev Community Dent. 2018;8(2):137-44. DOI: 10.4103/jispcd.JISPCD_9_18 
15. Zhang $M$, Zhou M, Tang F, Wang $Y$, Nie H, Zhang L, et al. Knowledge, attitude, and practice regarding COVID-19 among healthcare workers in Henan, China. J Hosp Infect. 2020;105(2):183-7. DOI: 10.1016/j.jhin.2020.04.012

16. Alzoubi $\mathrm{H}$, Alnawaiseh $\mathrm{N}$, Al-Mnayyis $\mathrm{A}$, Lubad M, Aqel A, AlShagahin H. COVID-19 - Knowledge, Attitude and Practice among Medical and Non-Medical University Students in Jordan. J Pure ApplMicrobiol. 2020;14(1):17-24. DOI: 10.22207/JPAM.14.1.04

17. Ather A, Patel B, Ruparel NB, Diogenes A, Hargreaves KM. Coronavirus Disease 19 (COVID-19): Implications for Clinical Dental Care. J Endod. 2020;46(5):584-95. DOI: 10.1016/j.joen. 2020.03.008

18. Checchi V, Bellini P, Bencivenni D, Consolo U. COVID-19 dentistry-related aspects: a literature overview. Int Dent J. 2020;10.1111/idj.12601.DOI: 10.1111/idj.12601
19. Using Personal Protective Equipment (PPE) [Internet]. Atlanta: Centers for Disease Control and Prevention; [cited 2020 Aug 19]. Available from: https://www.cdc.gov/coronavirus/2019ncov/hcp/using-ppe.html

20. Hegde $\mathrm{S}$. Which type of personal protective equipment (PPE) and which method of donning or doffing PPE carries the least risk of infection for healthcare workers? Evid Based Dent. 2020;21(2): 74-6. DOI: 10.1038/s41432-020-0097-3

21. Kampf G, Todt D, Pfaender S, Steinmann E. Persistence of coronaviruses on inanimate surfaces and their inactivation with biocidal agents. J Hosp Inf. 2020;104(3):246-51. DOI: 10.1016/j.jhin.2020.01.022

22. Peng $X, X u X$, Li Y, Cheng L, Zhou $X$, Ren B. Transmission routes of 2019-nCoV and controls in dental practice. Int J Oral Sci. 2020;12(1):9. DOI: 10.1038/s41368-020-0075-9

23. Ghai S. Teledentistry during COVID-19 pandemic. Diabetes MetabSyndr. 2020;14(5):933-5. DOI: 10.1016/j.dsx.2020.06.029 